\title{
Impact of environmental temperatures on resistance to organophosphate insecticides in Aedes aegypti from Trinidad
}

\author{
Karen A. Polson, ${ }^{1}$ William G. Brogdon, ${ }^{2}$ Samuel C. Rawlins, ${ }^{3}$ \\ and Dave D. Chadee ${ }^{1}$
}

Suggested citation Polson KA, Brogdon WG, Rawlins SC, Chadee DD. Impact of environmental temperatures on resistance to organophosphate insecticides in Aedes aegypti from Trinidad. Rev Panam Salud Publica. 2012;32(1):1-8.

\begin{abstract}
Objective. To examine the effects of increasing larval rearing temperatures on the resistance status of Trinidadian populations of Aedes aegypti to organophosphate (OP) insecticides.

Methods. In 2007-2008, bioassays and biochemical assays were conducted on A. aegypti larvae collected in 2006 from eight geographically distinct areas in Trinidad (Trinidad and Tobago). Larval populations were reared at four temperatures $\left(28 \pm 2{ }^{\circ} \mathrm{C}, 32^{\circ} \mathrm{C}, 34^{\circ} \mathrm{C}\right.$, and $\left.36^{\circ} \mathrm{C}\right)$ prior to bioassays with OP insecticides (fenthion, malathion, and temephos) and biochemical assays for esterase enzymes.

Results. Most larval populations reared at $28 \pm 2{ }^{\circ} \mathrm{C}$ were susceptible to fenthion $(\geq 98 \%$ mortality) but resistant to malathion and temephos ( $<80 \%$ mortality). A positive association was found between resistance to $O P$ insecticides and increased activities of $\alpha$ - and $\beta$-esterases in larval populations reared at $28 \pm 2^{\circ} \mathrm{C}$. Although larval populations reared at higher temperatures showed variations in resistance to OPs, there was a general increase in susceptibility. However, increases or decreases in activity levels of enzymes did not always correspond with an increase or decrease in the proportion of resistant individuals reared at higher temperatures. Conclusions. Although global warming may cause an increase in dengue transmission, based on the current results, the use of insecticides for dengue prevention and control may yet be effective if temperatures increase as projected.
\end{abstract}

Key words Culicidae; aedes; mosquito control; insecticide resistance; insecticides, organophosphate; temperature; Trinidad and Tobago.

In the past 30 years, there has been a resurgence of epidemic dengue and an emergence of dengue hemorrhagic fever (DHF) as a global public health problem $(1,2)$. This has been due, in part, to the interaction of several risk factors related

1 University of the West Indies, St. Augustine, Trinidad and Tobago. Send correspondence to: Dave D. Chadee, chadee@tstt.net.tt

2 Centers for Disease Control and Prevention, Atlanta, Georgia, United States of America.

3 Caribbean Epidemiology Centre (CAREC), Port of Spain, Trinidad and Tobago. to the environment, the virus, the host population, and vector bionomics (3-5), and to the widespread development of insecticide resistance in the Aedes aegypti mosquito $(6,7)$. Mosquitoes and other poikilothermic vector organisms are sensitive to climatic factors such as temperature, precipitation, and humidity (8).

Environmental temperature may have an effect on mosquito physiology and thus may also influence pathogen multiplication and transmission (9). Therefore, changes in environmental temperatures in the direction consistent with global warming trends may be expected to exacerbate the emergence or resurgence of a number of vector-borne diseases, such as malaria and dengue $(8,10,11)$. The effect of the expected increase in temperature on the A. aegypti mosquito is of particular concern with regard to the transmission of dengue (11-13). It is expected that with increased temperatures, smaller mosquitoes, which feed more frequently, will be 
produced; the geographic range of the mosquitoes will expand; and the extrinsic incubation period of the virus will be shortened $(11,13)$.

Epidemiological research has shown that temperature is a key "predictor" of dengue infection (14). Patz et al. (11) estimated that for regions where dengue is already present, a mean temperature increase of about $1^{\circ} \mathrm{C}$ increases the aggregate epidemic risk by an average of $31 \%-47 \%$. The Intergovernmental Panel on Climate Change (IPCC) reported that rising temperatures and changing rainfall would have mixed effects on the potential for infections such as malaria and dengue worldwide (15). They concluded that in areas with limited public health resources, increased temperatures in conjunction with adequate rainfall would likely cause certain mosquitoborne infections to move to higher altitudes and higher latitudes, thus extending disease transmission seasons in some non-endemic locations (15). An association between climate variability and dengue in the Caribbean was also demonstrated in studies conducted in the Caribbean between 2002 and 2005 $(16,17)$. In these studies, the seasonality of dengue epidemics was shown to be associated with temperature and precipitation.

Dengue and DHF outbreaks have been occurring in the Caribbean with greater frequency and intensity with shortened intervals between outbreaks since the 1990s (18). The prevention and control of dengue is aimed at the $A$. aegypti vector, with heavy emphasis on chemical control with insecticides. Organophosphate (OP) insecticides such as fenthion, malathion, and temephos have been used in the Caribbean region to control A. aegypti for the last 40 years (6). However, the continued reliance on these insecticides has resulted in the development of mosquito resistance to the insecticide, which has created a problem for vector control programs $(3,6,19)$.

Temperature and insecticides are two extrinsic factors that can affect the genetic structure of mosquitoes (20). While research has shown that the dengue vector is affected by increases in temperature and insecticide selection pressure, to the best of the authors' knowledge, the effects of increased rearing temperatures on the insecticide resistance status of A. aegypti were not known prior to this study. Although uncertainties remain re- garding the magnitude of the impact of climate change and global warming on public health, it seems clear that the expected increase in temperature will have some public health ramifications, such as the expansion of the geographic range of insect vectors, which would result in increased transmission of vector-borne diseases (21-23). This scenario does not augur well for dengue prevention and control, as insecticide resistance in $A$. aegypti already poses a challenge. To address this issue, this study examined the effects of larval rearing temperatures on the insecticide resistance status of Trinidadian populations of $A$. aegypti.

\section{MATERIALS AND METHODS}

\section{Mosquito collection}

In 2006, A. aegypti eggs were collected from eight geographically distinct areas in Trinidad (Trinidad and Tobago) (Figure 1), using enhanced ovitraps (24). The Port of Spain strains (St. Clair, St. James, and Sea Lots) are located in the northwestern part of Trinidad. The Haleland Park strain is located on the outskirts of Port of Spain, the Curepe and Valencia strains in the northeastern part of the island, the Spring Vale strain in the central part, and the San Fernando strain in the southern part of the island. Mosquito colonies were established for each population, and in 2007-2008 tests were conducted on late 3rd- to early 4th-stage larvae of the F2-F4 generations. A strain of insecticide-susceptible A. aegypti mosquitoes from the Caribbean Epidemiology Centre (CAREC) that has not been exposed to insecticides for more than 30 years was used as the reference susceptible population.

\section{Larval treatment}

Mosquito eggs were vacuum-hatched and one-day-old larvae were transferred to larval rearing trays at a density of 250-300 larvae per tray. Prior to the conduct of the assays, one set of larvae was maintained in the insectary at $28^{\circ} \mathrm{C}$ $\pm 2^{\circ} \mathrm{C}$. Results obtained from tests carried out on this set of larvae were used as the baseline for further comparisons. Batches of larvae from each population were also placed in incubators (LabLine ${ }^{\circledR}$ Biotronette ${ }^{\circledR}$ Mark II Plant Growth Regulator Chambers) set at constant

FIGURE 1. Map of Trinidad showing locations of Aedes aegypti populations examined in research on impact of environmental temperature on resistance to organophosphate insecticides, Trinidad, Trinidad and Tobago, 2007-2008

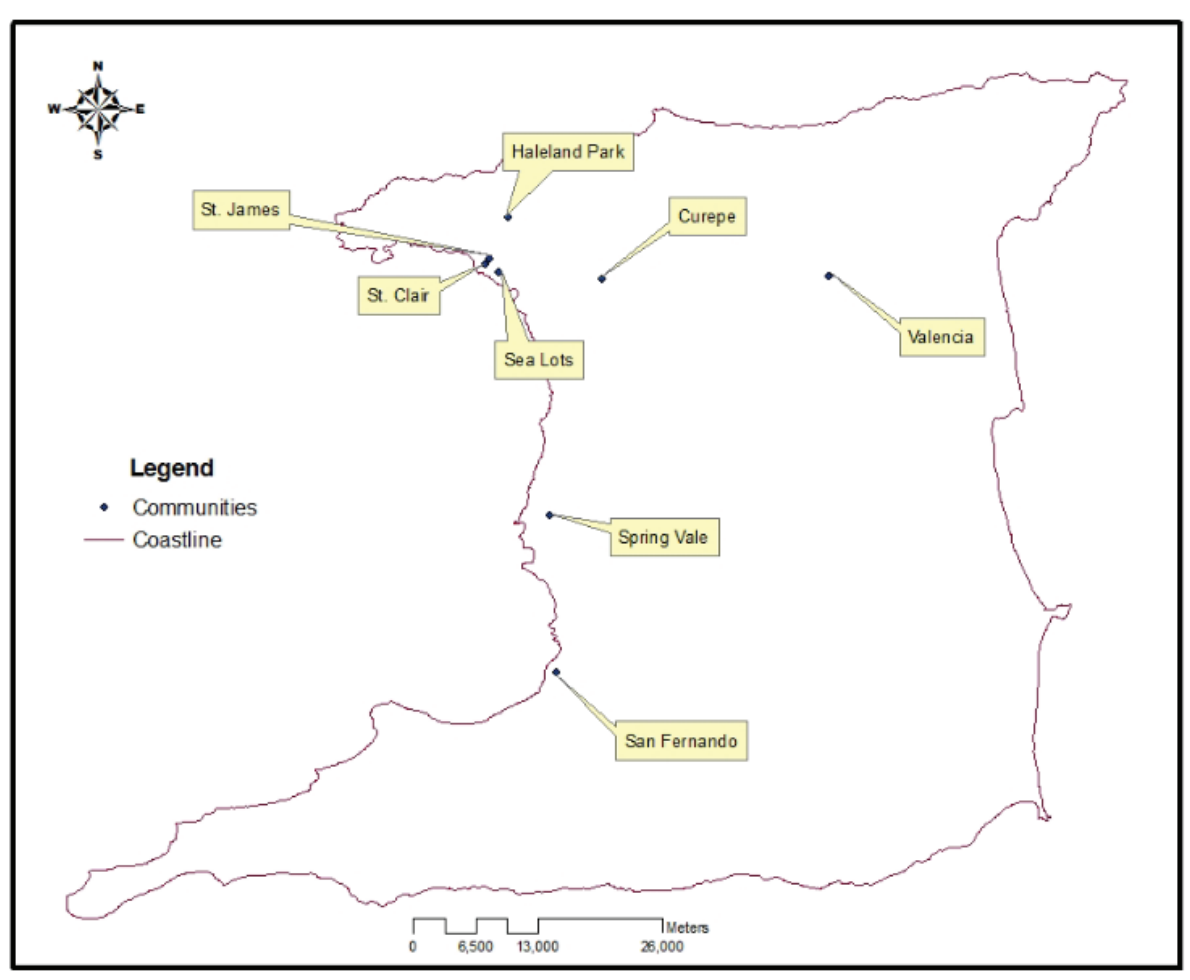


temperatures of $32^{\circ} \mathrm{C}, 34^{\circ} \mathrm{C}$, and $36^{\circ} \mathrm{C}$. All larvae were kept at the respective temperatures and maintained on a diet of rabbit chow until they developed to the late 3rd or early 4th stage, after which time they were removed and assays conducted. Mosquito larvae did not survive at environmental temperatures above $36^{\circ} \mathrm{C}$, so that was the maximum temperature used in the experiments.

\section{Larval bioassays}

Bioassays were conducted using the method developed by the U.S. Centers for Disease Control and Prevention (CDC) and diagnostic dosages for temephos, malathion, and fenthion were determined using the CAREC reference susceptible population, as described in detail by Polson et al. in a previous (2010) study (19). Larval populations and controls from each temperature regime were then subjected to the known diagnostic dosage of each insecticide and mortality counts made every 15 minutes up to a maximum of 2 hours, as outlined in the 2010 study by Polson et al. (19). Tests were carried out in the laboratory, which was maintained at a constant temperature of $23^{\circ} \mathrm{C} \pm 1^{\circ} \mathrm{C}$.

Mean percentage mortalities were calculated after 2-hour exposure to insecticides for larval population from each temperature regime and comparisons made with the CAREC reference susceptible population. Statistical analyses were carried out using Kruskal-Wallis and Dunn's non-parametric tests, comparing mean percentage mortalities of the CAREC reference strain with the field populations. Mosquito populations were assessed as being resistant or susceptible using the criteria defined by Davidson \& Zahar (1973) and modified by World Health Organization (WHO) (1998) (25, 26). Mosquitoes showing $98 \%-100 \%$ mortality were classified as "susceptible"; those with $<80 \%$ mortality as "resistant"; and those with $80 \%-97 \%$ mortality as "incipiently resistant." Data obtained on the CAREC strain were used as the benchmark for comparison with the field populations.

\section{Biochemical assays}

Thirty mosquito larvae from each population were assayed for $\alpha$ - and $\beta$-esterases as well as p-nitrophenyl acetate (PNPA) esterases, following the protocols described by Polson et al. in a 2011 study (7). Mosquitoes were also assayed to determine the amount of total proteins in each mosquito. Controls were included in the enzyme assays and treated in the same manner as the mosquito homogenates (7).

Absorbance values, which were obtained for mosquito replicates, were corrected in relation to the volume of mosquito homogenates, the enzyme activity unit, and the total protein content of each mosquito. Activity levels of $\alpha$ - and $\beta$-esterases were expressed in $\mathrm{nmol} / \mathrm{mg}$ $\mathrm{ptn} / \mathrm{min}$, and the mean change in absorbance levels of the PNPA-esterases was expressed as delta abs/mg ptn/min. Data for each temperature regime were analyzed, and comparisons of the mean enzyme activity levels of each enzyme for each larval population were made within and among regimes. Data were analyzed using methods developed by WHO and Brazil's Ministry of Health $(26,27)$. The means of enzyme activity levels for larvae at each temperature were compared with the enzyme activity levels of the CAREC strain by KruskalWallis and Tukey's non-parametric tests $(P<0.05)$. Analyses were also carried out to assess the relation between the bioassay and biochemical results obtained at the different temperatures for each larval population.

\section{RESULTS}

\section{Larval bioassays}

The diagnostic dosages (DDs) that were established for fenthion, malathion, and temephos were $1 \mathrm{mg} / 1,2 \mathrm{mg} / 1$, and $2 \mathrm{mg} / 1$, respectively. Results showed that after 2-hour exposure to each insecticide at their respective DD, the CAREC reference strain, reared at $28^{\circ} \mathrm{C} \pm 2^{\circ} \mathrm{C}$, showed $100 \%$ mortality to fenthion and temephos but $97.5 \%$ mortality to malathion. Based on the WHO criteria for resistance classification, the CAREC strain was susceptible to all three insecticides (with mortalities $\geq 97.5 \%$ ) and was thus suitable as a reference population. Field populations were determined to be significantly different from the CAREC reference strain if $P<0.05$.

Fenthion. The susceptibility status of the CAREC reference susceptible strain remained constant for larvae reared at all temperatures (Figure 2). Most larval populations reared at $28^{\circ} \mathrm{C} \pm 2{ }^{\circ} \mathrm{C}$ were either susceptible ( $\geq 98 \%$ mortality) or incipiently resistant $(80.0 \%-97.0 \%$ mortality) to fenthion. The Sea Lots and St. James populations were resistant to fenthion, with $76.8 \%$ and $65.5 \%$ mortality, respectively (Figure 2). All populations that showed susceptibility to fen-

FIGURE 2. Response to fenthion in nine different Aedes aegypti larval populations ${ }^{\mathrm{a}}$ reared at four different temperatures, Trinidad, Trinidad and Tobago, 2007-2008

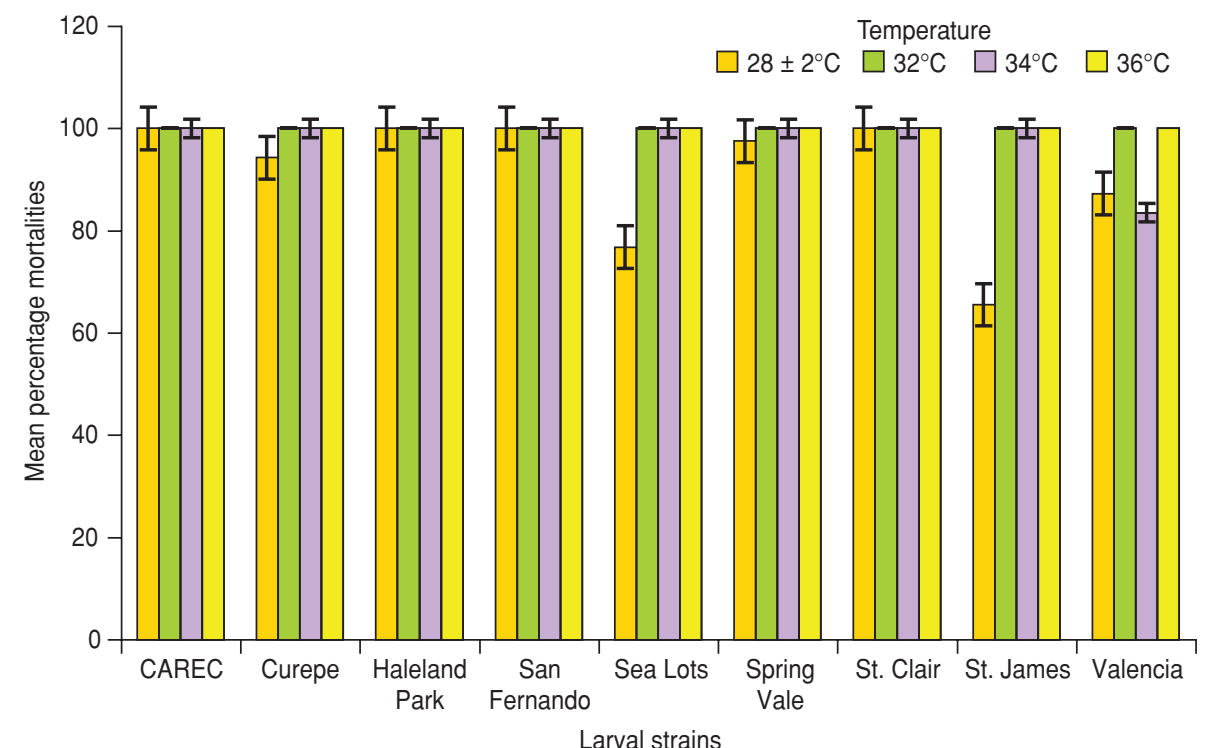

a One strain each from eight geographically distinct areas plus one reference susceptible laboratory (CAREC, Caribbean Epidemiology Centre) strain. 
thion at $28^{\circ} \mathrm{C} \pm 2^{\circ} \mathrm{C}$ were still susceptible when reared at increased temperatures of $32^{\circ} \mathrm{C}, 34^{\circ} \mathrm{C}$, and $36^{\circ} \mathrm{C}$. However, all populations reared at $28^{\circ} \mathrm{C} \pm 2^{\circ} \mathrm{C}$ that were incipiently resistant or resistant to fenthion showed susceptibility decrease in the proportion of resistant individuals at the higher rearing temperatures. The Valencia population was the only one that fluctuated in susceptibility levels, becoming more susceptible at $32^{\circ} \mathrm{C}$, less susceptible at $34^{\circ} \mathrm{C}$, and then more susceptible at $36^{\circ} \mathrm{C}$ (Figure 2).

Malathion. Slight variations were observed in the susceptibility levels of CAREC strain larvae reared at all temperatures when they were exposed to malathion. These variations were, however, not significant $(P>0.05)$ and the strain still remained susceptible $(\geq 98.0 \%$ mortality) (Figure 3). Five of the eight populations that were reared at $28^{\circ} \mathrm{C} \pm$ $2^{\circ} \mathrm{C}$ were found to be resistant to malathion, with mortalities ranging from $56.2 \%$ (Haleland Park) to $77.5 \%$ (Curepe), while the other three populations were incipiently resistant $(80.0 \%-93.5 \%$ mortality) (Figure 3). All populations, when reared at $32^{\circ} \mathrm{C}$, increased in susceptibility to malathion and were incipiently resistant. However, the St. James and Valencia populations, although increasing in susceptibility to malathion, were still resistant, with mortalities of $79.0 \%$ and $76.5 \%$, respectively (Figure 3 ). When larval populations were reared at $34^{\circ} \mathrm{C}$, most continued to show a decrease in the proportion of individuals resistant to malathion, compared to those reared at the lower temperatures. However, the San Fernando, Sea Lots, and St. Clair populations were the only ones reared at $34^{\circ} \mathrm{C}$ that had reduced susceptibility, with mortalities of $78.5 \%, 79.2 \%$, and $85.2 \%$, respectively (Figure 3 ). Most of the larval populations that were reared at $36^{\circ} \mathrm{C}$ showed susceptibility decrease in the proportion of individuals resistant to malathion, but the Curepe and Valencia populations showed reduced susceptibility, with mortalities of $83.2 \%$ and $73.5 \%$, respectively. There were no differences observed in the Spring Vale population reared at $34^{\circ} \mathrm{C}$ and $36^{\circ} \mathrm{C}$, in that larvae were completely susceptible to malathion at both temperatures (100.0\% mortality) (Figure 3).

Temephos. The CAREC strain larvae, reared at different temperatures, showed

FIGURE 3. Response to malathion in nine different Aedes aegypti larval populations ${ }^{\mathrm{a}}$ reared at four different temperatures, Trinidad, Trinidad and Tobago, 2007-2008

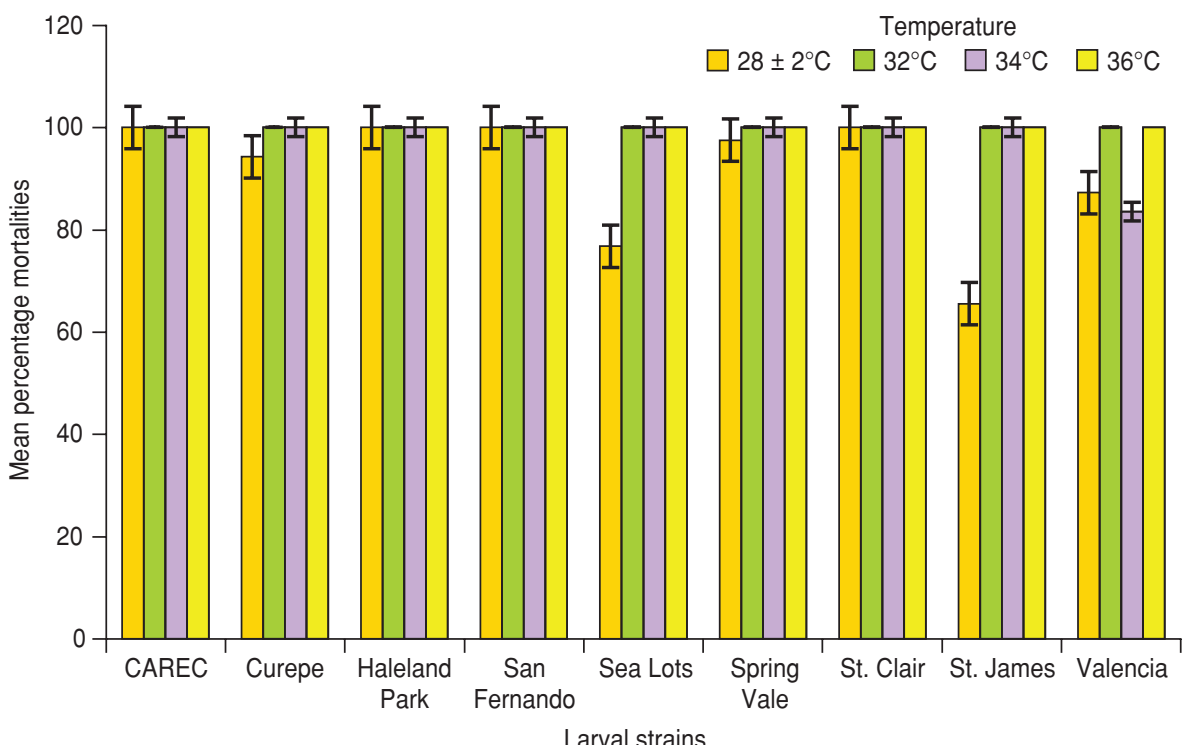

a One strain each from eight geographically distinct areas plus one reference susceptible laboratory (CAREC, Caribbean Epidemiology Centre) strain.

FIGURE 4. Response to temephos in nine different Aedes aegypti larval populations ${ }^{\mathrm{a}}$ reared at four different temperatures, Trinidad, Trinidad and Tobago, 2007-2008

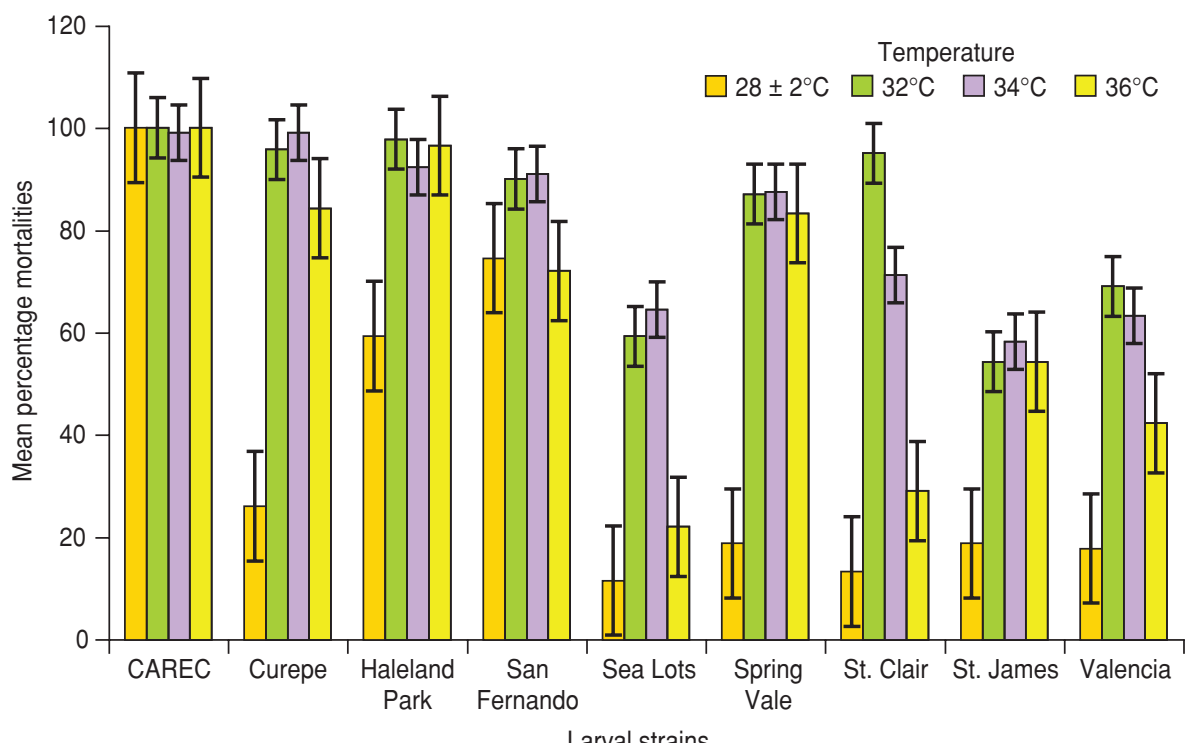

Larval strains

a One strain each from eight geographically distinct areas plus one reference susceptible laboratory (CAREC, Caribbean Epidemiology Centre) strain.

variations in the levels of susceptibility to temephos but still remained susceptible. The variations did not result in any significant difference in susceptibility levels $(P>0.05)$. All larval populations that were reared at $28^{\circ} \mathrm{C} \pm 2^{\circ} \mathrm{C}$ showed resistance to temephos, with mortalities ranging from $11.5 \%$ (Sea Lots) to $74.5 \%$
(San Fernando) (Figure 4). Susceptibility levels to temephos were higher in all larval populations reared at $32^{\circ} \mathrm{C}$, with percentage mortalities ranging from $54.25 \%$ (St. James) to $97.7 \%$ (Haleland Park). Most larval populations reared at $34^{\circ} \mathrm{C}$ showed higher levels of susceptibility to temephos than those reared at $32^{\circ} \mathrm{C}$, 
but the differences were not significant $(P>0.05)$ (Figure 4$)$. On the other hand, most populations that were reared at $36^{\circ} \mathrm{C}$ showed reduced susceptibility to temephos, compared to the populations reared at $34^{\circ} \mathrm{C}$. The Haleland Park population that was reared at $36^{\circ} \mathrm{C}$ was the only one that showed an increase in susceptibility to temephos ( $96.5 \%$ mortality) (Figure 4).

\section{Biochemical assays}

$\boldsymbol{\alpha}$-esterases. The lowest activity levels of $\alpha$-esterases observed in the CAREC strain were in larvae reared at $28^{\circ} \mathrm{C} \pm 2{ }^{\circ} \mathrm{C}(109.8$ $\mathrm{nmol} / \mathrm{mg} \mathrm{ptn} / \mathrm{min}$ ), but the esterase activity levels were higher in larvae reared at the higher temperatures (Figure 5). Although the activity levels of $\alpha$-esterases declined between larvae reared at $32^{\circ} \mathrm{C}$ and those reared at $36^{\circ} \mathrm{C}$, the differences were not significant $(P>0.05)$.

All larval populations except the Spring Vale, St. Clair, and Valencia strains showed an increase in the activity levels of $\alpha$-esterases in larvae reared at $32^{\circ} \mathrm{C}$ versus those reared at $28^{\circ} \mathrm{C} \pm$ $2^{\circ} \mathrm{C}$. The levels were again higher in only three populations reared at $34^{\circ} \mathrm{C}$, namely San Fernando $(658.0 \mathrm{nmol} / \mathrm{mg}$ $\mathrm{ptn} / \mathrm{min})$, St. Clair (733.9 nmol/mg ptn/ min), and Valencia (809.1 nmol/mg ptn/ min) (Figure 5). The activity levels of the $\alpha$-esterases were lower in most larval populations reared at $36^{\circ} \mathrm{C}$ versus those reared at $34^{\circ} \mathrm{C}$, with activity levels in the former group ranging from 437.34 $\mathrm{nmol} / \mathrm{mg} \mathrm{ptn} / \mathrm{min}$ (Sea Lots) to 774.12 $\mathrm{nmol} / \mathrm{mg} \mathrm{ptn} / \mathrm{min}$ (Valencia) (Figure 5).

$\boldsymbol{\beta}$-esterases. The mean activity level of the $\beta$-esterases in the CAREC strain reared at $28^{\circ} \mathrm{C} \pm 2{ }^{\circ} \mathrm{C}$ was $207.53 \mathrm{nmol} /$ $\mathrm{mg}$ ptn/min. The Sea Lots and Spring Vale strains reared at $28^{\circ} \mathrm{C} \pm 2^{\circ} \mathrm{C}$ had lower activity levels of $\beta$-esterases than the CAREC strain larvae reared at the same temperature (Figure 6). The activity levels of the $\beta$-esterases fluctuated in all larval populations reared at the higher temperatures, with levels increasing in all populations reared at $32^{\circ} \mathrm{C}$ except the St. Clair strain (Figure 6). All larval populations reared at $34^{\circ} \mathrm{C}$ except Valencia showed increases in the activity levels of $\beta$-esterases versus those observed in larvae reared at $32^{\circ} \mathrm{C}$. $\beta$-esterase activity levels were lower in all larval populations reared at $36^{\circ} \mathrm{C}$ versus those reared at $34^{\circ} \mathrm{C}$, with the levels

FIGURE 5. Mean activity levels of $\beta$-esterases in nine different Aedes aegypti larval populations ${ }^{a}$ reared at four different temperatures, Trinidad, Trinidad and Tobago, 2007-2008

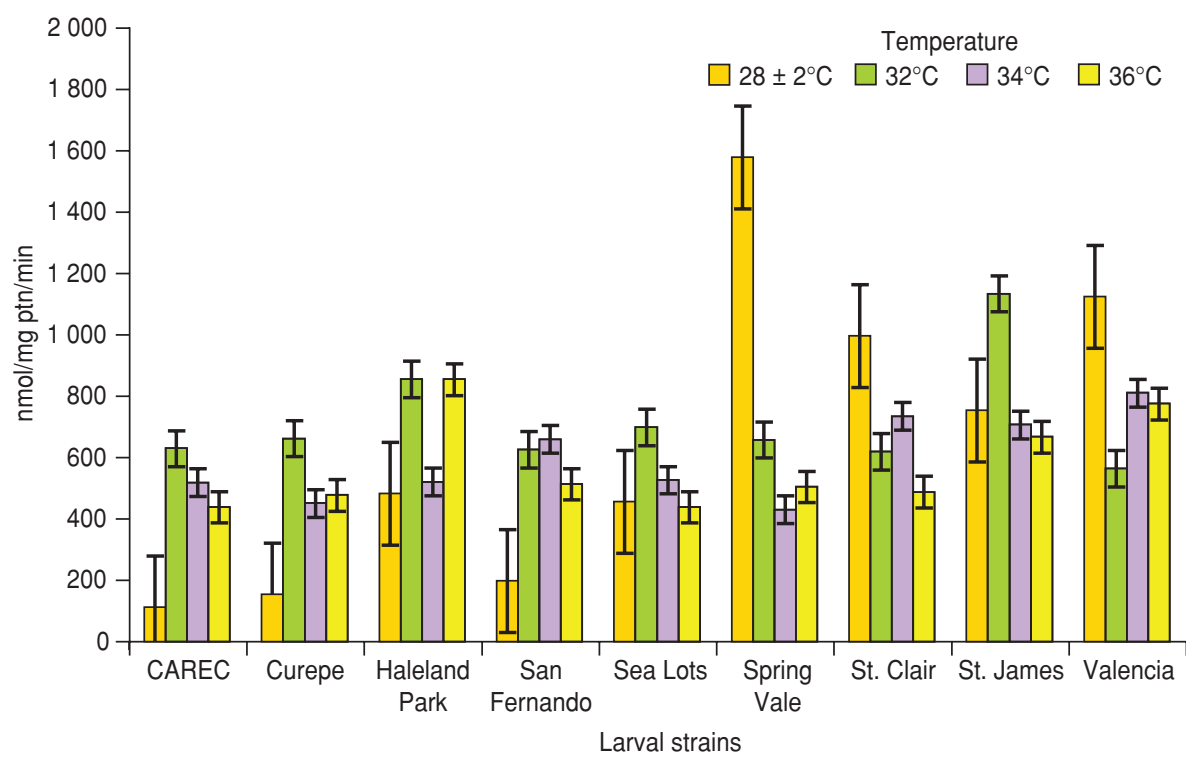

a One strain each from eight geographically distinct areas plus one reference susceptible laboratory (CAREC, Caribbean Epidemiology Centre) strain.

FIGURE 6. Mean activity levels of $\beta$-esterases in nine different Aedes aegypti larval populations ${ }^{a}$ reared at four different temperatures, Trinidad, Trinidad and Tobago, 2007-2008

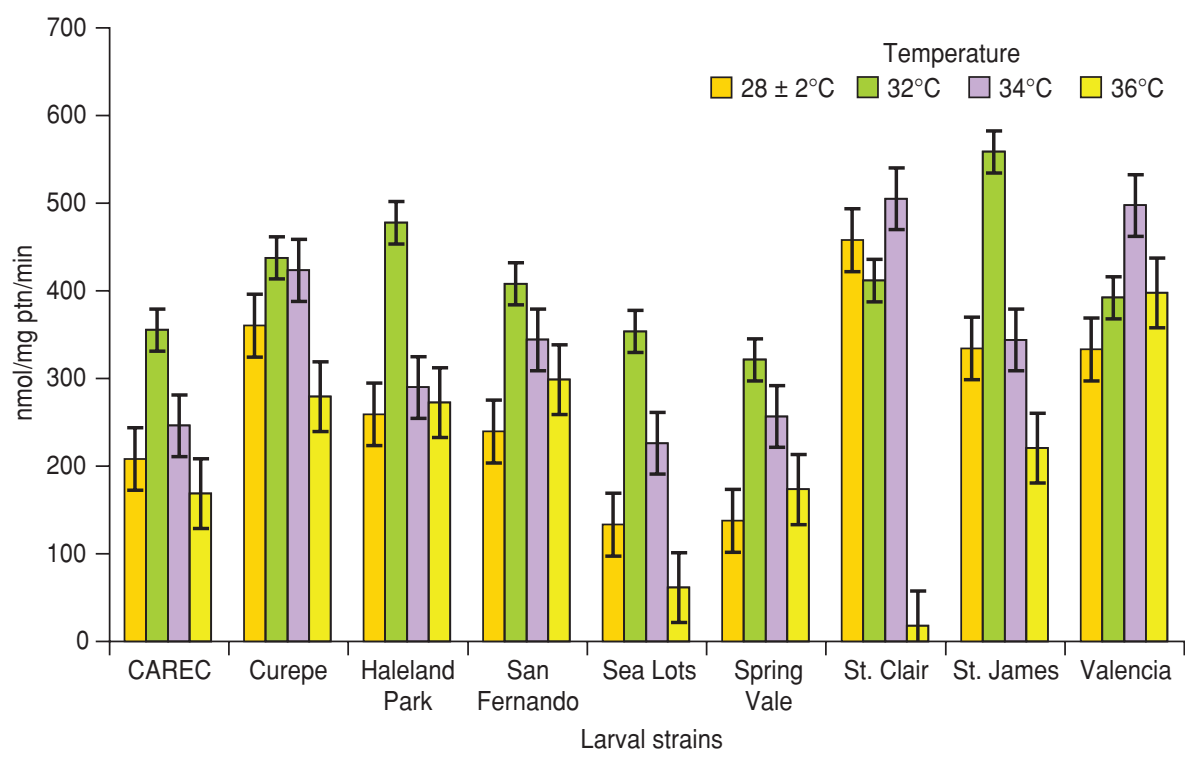

a One strain each from eight geographically distinct areas plus one reference susceptible laboratory (CAREC, Caribbean Epidemiology Centre) strain.

in the former group ranging from 17.26 $\mathrm{nmol} / \mathrm{mg} \mathrm{ptn} / \mathrm{min}$ (St. Clair) to 396.54 (Valencia) (Figure 6).

PNPA-esterases. The change in mean PNPA-esterase absorbance levels in larval populations reared at $28 \pm 2{ }^{\circ} \mathrm{C}$ was $0.02 \mathrm{mg} \mathrm{ptn} / \mathrm{min}$ for all populations except the San Fernando and Spring Vale strains, which registered levels of $0.01 \mathrm{mg}$ $\mathrm{ptn} / \mathrm{min}$ (Figure 7). The PNPA-esterase absorbance levels remained unchanged for all populations reared at $32^{\circ} \mathrm{C}$ except the St. Clair strain, which showed a decrease $(0.01 \mathrm{mg} \mathrm{ptn} / \mathrm{min})$ versus the levels seen in larvae reared at $28 \pm 2{ }^{\circ} \mathrm{C}$ 
FIGURE 7. Mean change in absorbance levels of PNPA-esterases in nine different Aedes aegypti larval populations $\mathrm{s}^{\mathrm{a}}$ reared at four different temperatures, Trinidad, Trinidad and Tobago, 2007-2008

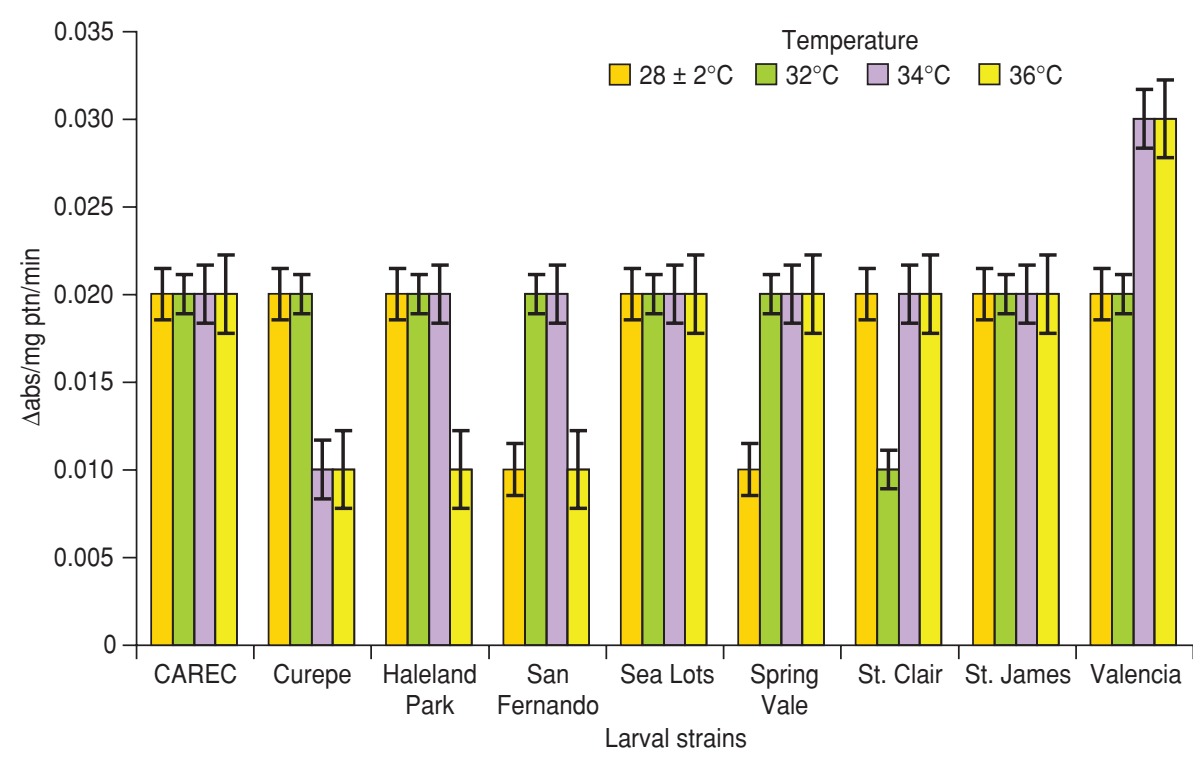

a One strain each from eight geographically distinct areas plus one reference susceptible laboratory (CAREC, Caribbean Epidemiology Centre) strain.

(Figure 7). For larval populations reared at $34^{\circ} \mathrm{C}$, changes in PNPA-esterase absorbance levels were observed in only three strains, with a decrease or increase of $0.01 \mathrm{mg} \mathrm{ptn} / \mathrm{min}$ versus populations reared at $32^{\circ} \mathrm{C}$ (Figure 7). PNPA-esterase absorbance levels were unchanged in all larval populations reared at $36^{\circ} \mathrm{C}$ except the Haleland Park and San Fernando strains, which showed a decrease of 0.01 $\mathrm{mg} \mathrm{ptn} / \mathrm{min}$ versus those seen in larvae reared at $34^{\circ} \mathrm{C}$.

\section{DISCUSSION}

The projected increases in temperature due to climate change and global warming are expected to affect the $A$. aegypti mosquito, the dengue virus, and [subsequently] the transmission of the disease $(11,13)$. It is expected that with increased temperatures, the life cycle of the mosquito will be shortened; smaller mosquitoes, which feed more frequently, will be produced; the geographic range of the mosquitoes will expand; and the extrinsic incubation period of the virus will be shortened $(11,13)$. Resistance is a genetically controlled phenomenon in which the resistance genes are passed on from one generation to another. The shortening of the mosquito life cycle with increased environmental temperatures will un- doubtedly result in the propagation of resistance through selection.

The IPCC has projected increases in average temperatures in tropical countries of $1.4^{\circ} \mathrm{C}-5.8^{\circ} \mathrm{C}$ by the year 2100 , as a result of climate change (15). In the current study, environmental temperatures under which larvae were reared ranged from $28^{\circ} \mathrm{C} \pm 2^{\circ}-36^{\circ} \mathrm{C}$, and corresponding water temperatures ranged from $30.3^{\circ} \mathrm{C}-$ $32.7^{\circ} \mathrm{C}$. The upper-limit rearing temperature used in these experiments was $36^{\circ} \mathrm{C}$ because environmental temperatures above that (with water temperatures ranging from $25.4^{\circ} \mathrm{C}-36.5^{\circ} \mathrm{C}$ ) resulted in $100 \%$ larval mortality. These results are supported by a 2009 study by Hemme et al., who found that the temperatures in water storage drums in Trinidad that were negative for the presence of $A$. aegypti larvae were significantly warmer than in drums that were positive for the presence of larvae (28).

Fenthion, malathion, and temephos are the OP insecticides that are widely used in the vector control program in Trinidad. Fenthion is applied perifocally or by space sprays as an adulticide, whereas malathion is applied as an adulticide by thermal fog or ultra-low volume (ULV) spray during a dengue outbreak or in response to complaints of high mosquito densities $(6,29)$. While fenthion and malathion are not routinely used, temephos is the only larvicide applied in potable water for the control of A. aegypti larvae in Trinidad.

Baseline results of this study confirmed the presence of resistance in larval populations to one or all insecticides assayed. The resistance to fenthion and malathion seen in the larvae could be due to multiple resistance (several resistance mechanisms present in one population) stemming from the temephos resistance. The high levels of resistance to temephos that were observed point to the need for a reduction in the use of this insecticide, as continued use will result in its becoming ineffective in mosquito control. Temperature-based studies, however, have demonstrated that as rearing temperatures increased above baseline $\left(28^{\circ} \mathrm{C} \pm 2^{\circ} \mathrm{C}\right)$, the temperature coefficient was positive in most cases, suggesting that temephos was more effective in these instances.

The toxicity of insecticides is affected by temperature changes, in that OP toxicity increases with increasing temperatures, showing a positive temperature coefficient (30). Results of this study showed that as the rearing temperatures increased, OP insecticide toxicity increased. Mosquito populations reared at higher temperatures were more susceptible to one or all of the three OP insecticides than populations reared at the baseline temperature of $28^{\circ} \mathrm{C} \pm 2^{\circ} \mathrm{C}$. These results were, however, dissimilar to those of Patil et al. (1996), who found that pre-exposing larvae to high temperatures resulted in increased tolerance to the insecticide bendiocarb (31).

Imasheva et al. (1997) showed that temperature affects not only insecticides but also biological molecules such as enzymes and proteins, which play an important role in the survival of many organisms (32). Esterases are the detoxification enzymes involved mainly in insecticide resistance, and elevated activity levels of these enzymes observed in larval populations have contributed to the demonstrated resistance to OP insecticides $(33,34)$. In Latin America and the Caribbean, several $A$. aegypti populations show a strong resistance to OP insecticides that correlates with elevated activities of at least one detoxification enzyme family (35). In the current study, a positive association was found between resistance to OP insecticides and increased activity levels of $\alpha$ - and $\beta$-esterases in larval populations reared 
at $28^{\circ} \mathrm{C} \pm 2{ }^{\circ} \mathrm{C}$. In several instances, however, in larvae reared at higher temperatures, changes in susceptibility to insecticides and changes in the activity levels of detoxification enzymes were not associated, contradicting the hypotheses that any decrease in enzyme activity levels caused by increasing temperatures would result in an increase in the susceptibility of the larval populations to the respective insecticides, and vice versa. The differences in responses to insecticides observed in larval populations reared at higher temperatures could be due to the heterogeneity of the populations from various geographic locations and the varying levels of insecticide selection pressure in the field.

PNPA-esterases, which are $\alpha$ esterases, are associated with OP resistance in mosquitoes, with resistant populations showing elevated activity levels of these enzymes (36). While PNPA-esterases were found to be associated with temephos resistance in Brazilian populations of $A$. aegypti (37), they were not shown to be involved in OP resistance in the Caribbean populations assayed in the current study. Although PNPA-esterases may not be an important mechanism at the moment, continued selection pressure exerted by temephos use may result in the enhancement of this mechanism.

The current findings showed that increased larval rearing temperatures caused changes in the activity levels of esterase enzymes and also resulted in larvae being more susceptible to insecticides. This means that any modifications in the levels of resistance due to the impact of temperature could provide useful insight into the role that temperature could play in the evolution of insecticide resistance.

\section{Conclusions}

The results of the current study supported the authors' hypothesis that elevated temperatures would cause changes in insecticide resistance status in Caribbean populations of A. aegypti. Although there were variations across different types of insecticide, temperatures, and mosquito populations, overall, mosquitoes became more susceptible to OP insecticides with increasing temperatures. Insecticides remain the main weapon used in vector control programs aimed at combating the spread of dengue. Therefore, it appears that although global warming may cause an increase in dengue transmission, based on the current results, the weapons that are relied upon for dengue prevention and control may yet be effective if temperatures increase as projected. These results also increase understanding of how mosquitoes respond or adapt to increased temperatures and thus can contribute to the development of bestpractice management approaches to inform control measures and help predict disease transmission.

Acknowledgments. The authors would like to convey special thanks to the staff of both the Insect Vector Control Division in St Joseph, Trinidad, and the Port of Spain Health Corporation for their assistance in the collection of field specimens. They also thank the U.S. Centers for Disease Control and Prevention (CDC) for allowing the use of their facilities and providing resources for conduct of experiments. Finally, the authors are indebted to the Caribbean Epidemiology Centre (CAREC) for graciously supplying the CAREC reference susceptible Aedes aegypti strain.

\section{REFERENCES}

1. Gubler DJ. Dengue and dengue hemorrhagic fever: its history and resurgence as a global public health problem. In: Gubler DJ, Kuno G, editors. Dengue and dengue hemorrhagic fever. London: CAB International;1997. Pp. 1-22.

2. World Health Organization. Global Alert and Response (GAR). Dengue/dengue haemorrhagic fever. Geneva: WHO; c2010. Available from: http://www.who.int/csr/disease/ dengue/en Accessed 1 May 2010.

3. Georghiou GP, Wirth M, Tran H, Saume F, Knudsen AB. Potential for organophosphate resistance in Aedes aegypti (Diptera: Culicidae) in the Caribbean area and neighboring countries. J Med Entomol. 1987;24(3):290-4.

4. Pan American Health Organization. Dengue and dengue hemorrhagic fever in the Americas: guidelines for prevention and control. Washington: PAHO; 1994. (Scientific Publication No. 548).

5. Chadee DD, Williams FLR, Kitron UD. Epidemiology of dengue fever in Trinidad, West Indies: the outbreak of 1998. Ann Trop Med Parasitol. 2004;98(3):305-12.

6. Rawlins SC. Spatial distribution of insecticide resistance in Caribbean populations of Aedes aegypti and its significance. Rev Panam Salud Publica. 1998;4(4):243-51.

7. Polson KA, Rawlins SC, Brogdon WG, Chadee DD. Characterization of insecticide resistance in Trinidadian strains of Aedes aegypti mosquitoes. Acta Trop. 2011;117(1):31-8.

8. Githeko AK, Lindsay SW, Confalonieri UE, Patz JA. Climate change and vector-borne diseases: a regional analysis. Bull World Health Organ. 2000;78(9):1136-47.

9. Hardy JL, Houk EJ, Kramer LD, Reeves WC. Intrinsic factors affecting vector competence of mosquitoes for arboviruses. Annu Rev Entomol. 1983;28(1):229-62.

10. Hales S, de Wet N, Maindonald J, Woodward A. Potential effect of population and climate changes on global distribution of dengue fever: an empirical model. Lancet 2002; 360(9336):830-4.

11. Patz JA, Martens WJM, Focks DA, Jetten TH. Dengue fever epidemic potential as projected by general circulation models of global climate change. Environ Health Perspect. 1998; 106(3):147-53.

12. Mohammed A, Chadee DD. Effects of different temperature regimens on the development of Aedes aegypti (L.) (Diptera: Culicidae) mosquitoes. Acta Trop. 2011;119(1):38-43.

13. Shope RE. Global climate change and infectious diseases. Environ Health Perspect. 1991; 96:171-4.

14. Koopman JS, Prevots DR, Vaca Marin MA, Gomez Dantes H, Zarate Aquino ML, Longini $\mathrm{IM} J \mathrm{r}$, et al. Determinants and predictors of dengue infection in Mexico. Am J Epidemiol. 1991;133(11):1168-78.

15. Intergovernmental Panel on Climate Change. Contribution of Working Group II to the Fourth Assessment Report of the Intergovernmental Panel on Climate Change. In: Parry ML, Canziani OF, Palutikof JP, van der Linden PJ, Hanson CE, editors. Cambridge: Cambridge University Press; 2007.

16. Chen AA, Chadee DD, Rawlins SC, editors. Climate change impact on dengue: the Caribbean experience. Mona: University of the West Indies; 2006.

17. Chen AA, Taylor MA. Investigating the link between early season Caribbean rainfall and the El Niño + 1 year. Int J Climatology. 2002; 22(1):87-106.

18. Rawlins SC. Emerging and re-emerging vector-borne diseases in the Caribbean region. West Indian Med J. 1999;48(4):252-3.

19. Polson KA, Rawlins SC, Brogdon WG, Chadee DD. Organophosphate resistance in Trinidad and Tobago strains of Aedes aegypti. J Am Mosq Control Assoc. 2010; 26(4):403-10.

20. Yan G, Chadee DD, Severson DW. Evidence for genetic hitchhiking effect associated with insecticide resistance in Aedes aegypti. Genetics. 1998;148(2):793-800.

21. McMichael AJ, Campbell-Lendrum DH, Corvalán CF, Ebi KL, Githeko AK, Scheraga 
JD, et al., editors. Climate change and human health: risks and responses. Geneva: World Health Organization; 2003.

22. Patz JA, Epstein PR, Burke TA, Balbus JM. Global climate change and emerging infectious diseases. J Am Med Assoc. 1996;275(3): 217-23.

23. United Nations Environment Programme; World Health Organization; World Meteorological Organization. Methods of assessing human health vulnerability and public health adaptation to climate change. Geneva: WHO; 2003. (Health and Global Environmental Series No. 1).

24. Reiter P, Amador MA, Conlon N. Enhancement of the CDC ovitrap with hay infusions for daily monitoring of Aedes aegypti populations. J Am Mosq Control Assoc. 1991;7(1): 52-5.

25. Davidson G, Zahar AR. The practical implications of resistance of malaria vectors to insecticides. Bull World Health Organ. 1973;49(5): 475-83.

26. World Health Organization. Techniques to detect insecticide resistance mechanisms (field and laboratory manual). Geneva: WHO; 1998. (WHO/CDS/CPC/MAL/98.6).

27. Ministério da Saúde; Fundação Oswaldo Cruz (BR). Metodologia para quantificação de atividade de enzimas relacionadas com a resistência a inseticidas em Aedes aegypti. Brasília: MS; 2006.

28. Hemme RR, Tank JL, Chadee DD, Severson DW. Environmental conditions in water storage drums and influences on Aedes aegypti in Trinidad, West Indies. Acta Trop. 2009;112(1): 59-66.

29. Chadee DD. Aedes aegypti aboard boats at Port-of-Spain, Trinidad, West Indies (197282). Mosq News. 1984;44(1):1-3.

30. Horn DJ. Temperature synergism in integrated pest management. In: Hallman GJ, Denlinger DL, editors. Temperature sensitivity in insects and application in integrated pest management. Boulder, CO: Westview Press; 1998. Pp. 125-39.

31. Patil NS, Lole KS, Deobagkar DN. Adaptive larval thermotolerance and induced crosstolerance to propoxur insecticide in mosquitoes Anopheles stephensi and Aedes aegypti. Med Vet Entomol. 1996;10(3):277-82.

32. Imasheva AG, Loeschcke V, Zhivotovsky LA, Lazebny OE. Effects of extreme temperatures on phenotypic variation and developmental stability in Drosophila melanogaster and Drosophila buzzatii. Biol J Linn Soc. 1997;61(1): $117-26$.
33. Brogdon WG, McAllister JC. Insecticide resistance and vector control. Emerg Infect Dis. 1998;4(4):605-13.

34. Hemingway J, Boodington R, Harris J. Mechanisms of insecticide resistance in Aedes aegypti (L) (Díptera: Culicidae) from Puerto Rico. Bull Entomol. 1989;79(1):123-30.

35. Rodríguez MM, Bisset J, de Fernandez DM, Lauzán L, Soca A. Detection of insecticide resistance in Aedes aegypti (Diptera: Culicidae) from Cuba and Venezuela. J Med Entomol. 2001;38(5):623-8.

36. Karunaratne $\mathrm{SH}$, Vaughan A, Paton MG, Hemingway J. Amplification of a serine esterase gene is involved in insecticide resistance in Sri Lankan Culex tritaeniorhynchus. Insect Mol Biol. 1998;7(4):307-15.

37. Montella IR, Martins AJ, Viana-Medeiros PF, Lima JBP, Braga IA, Valle D. Insecticide resistance mechanisms of Brazilian Aedes aegypti populations from 2001 to 2004 . Am J Trop Med Hyg. 2007;77(3):467-77.

Manuscript received on 21 June 2011. Revised version accepted for publication on 5 January 2012.

RESUMEN Objetivo. Examinar los efectos del aumento de las temperaturas de desarrollo larvario sobre el estado de resistencia a los insecticidas organofosforados de las poblaciones de Aedes aegypti en Trinidad.

Repercusión de las temperaturas ambientales sobre la resistencia de Aedes aegypti a los insecticidas organofosforados en Trinidad

Palabras clave
Métodos. En 2007 y 2008 se llevaron a cabo ensayos biológicos y bioquímicos en larvas de A. aegypti recogidas en el 2006 de ocho áreas geográficamente separadas en Trinidad (Trinidad y Tabago). Las poblaciones larvarias se desarrollaron en cuatro temperaturas $\left(28 \pm 2{ }^{\circ} \mathrm{C}, 32{ }^{\circ} \mathrm{C}, 34{ }^{\circ} \mathrm{C}\right.$ y $\left.36^{\circ} \mathrm{C}\right)$ antes de los ensayos biológicos con insecticidas organofosforados (fentión, malatión y temefós) y los análisis bioquímicos para las enzimas de esterasa.

Resultados. La mayoría de las poblaciones larvarias que se desarrollaron a $28 \pm$ $2{ }^{\circ} \mathrm{C}$ fueron susceptibles al fentión (mortalidad $\geq 98 \%$ ) pero resistentes al malatión y al temefós (mortalidad $<80 \%$ ). Se encontró una asociación positiva entre la resistencia a los insecticidas organofosforados y la mayor actividad de $\alpha$ y $\beta$-esterasas en las poblaciones larvarias que se desarrollaron a $28 \pm 2{ }^{\circ} \mathrm{C}$. Aunque las poblaciones larvarias que se desarrollaron a temperaturas mayores mostraron variaciones en la resistencia a los organofosforados, hubo un aumento general de la sensibilidad. Sin embargo, los aumentos o las disminuciones en los niveles de actividad de las enzimas no siempre se correspondieron con un aumento o disminución en la proporción de individuos resistentes desarrollados a las temperaturas más altas.

Conclusiones. Aunque el recalentamiento del planeta puede causar un aumento de la transmisión del dengue, según los resultados de este estudio el uso de insecticidas para la prevención y el control del dengue todavía puede ser eficaz si las temperaturas aumentan según lo proyectado.

Culicidae; aedes; control de mosquitos; resistencia a los insecticidas; insecticidas organofosforados; temperatura ambiental; Trinidad y Tobago. 